\title{
An elementary educational issue of our times? Klaus Mollenhauer's (un)contemporary concern
}

\author{
Jan Masschelein Laboratory for Education and Society, KU Leuven \\ Jan.Masschelein@ppw.kuleuven.be
}

At the occasion of the publication of its English translation as Forgotten Connections: On Culture and Upbringing (2014) and as a modest attempt to honor Klaus Mollenhauer's work, I would like to insist on the persistent relevance of the basic intellectual endeavor that he proposed in his Vergessene Zusammenhänge. Über Kultur und Erziehung, first published in 1983. In order to do so I will comment on Mollenhauer's introduction and on what I consider to be a very fortunate formulation of an elementary educational issue in the second chapter of the book. Although I welcome the translation very much (including also the very helpful "Translators' Introduction") and am impressed by its quality, certainly given the difficulty of such a work especially in a field which has cultivated its own vocabulary in the German language, this will imply that I will have to touch briefly upon some translation issues.

I first encountered Klaus Mollenhauer as a young doctoral student at the Center for Philosophy of Education of the University of Leuven (Belgium) in the early 1980's. He came to Leuven; invited by my promoter Mariette Hellemans who, in her courses at the time, was dealing with the (German) tradition of critical hermeneutics and emancipatory pedagogy of which Mollenhauer was supposed to be one of the most influential representatives. A little later, together with Mariette Hellemans and my colleague PhD-student Paul Smeyers, we visited Mollenhauer in Göttingen where he taught at the university. On this occasion, we were warmly welcomed at his home where he expounded on the work he was doing regarding the 'educational' reading of paintings. He demonstrated many diapositives and also 'tested' his hypotheses on us regarding the interpretation of "Las Meninas" of Velasquez. He situated them in relation to those of Foucault and they became (together with many of the images that he showed us) a part of Forgotten Connections (see e.g. 2014, pp. 41-46). Afterwards, I had the opportunity to meet Mollenhauer at several conferences in Germany, including an intensive seminar on the work of Wilhelm Flitner organized by Helmut Peukert in Hamburg in 1989. The central question of this seminar concerned the 'place' of a 'general educational theory or study'. The central reference was to Flitners well-known phrase that such a theory relies on a 'basic pedagogical thought' ("einen Pädagogischen Grundgedankgang") which brings different central and internal concepts into relation such as: 'Bildung', 'Bildsamkeit', 'Bildungsweg', 'Bildungsziel' (see Peukert, 1992).

In retrospect, I can say that the seminar covered a decade in which German philosophy and theory of education ("Allgemeine Pädagogik" or "Allgemeine Erziehungswissenschaft"), after the emergence and tremendous flourishing of critical and emancipatory pedagogy in the sixties and seventies, felt itself increasingly colonized by sociology and critical social theory (reducing education in one way or another to ideology or socialization and disciplinary power). A decade also in which it was confronted with what it considered to be a worn-out idea of individual emancipation and a pointless critique of education (as theory and practice) that seemed to imply the end of education. Mollenhauer's Forgotten Connections was one of the first attempts to explicitly deal with these issues. In fact, in a short passage in the introduction and in an extensive footnote in the German version of 'Forgotten Connections' (which has not been translated in the English version) Mollenhauer explicitly states that the so-called "AntiPädagogik" (Anti-Pedagogy) - which he connects with the work of Miller and von Braunmühl, 
but also with a 'bad' reading of Foucault that ended up in the characterization of educational theory ("pädagogische Theorie") as 'power forming technological drill' ("herrschaftsförmigtechnologische Dressur", Mollenhauer, 1983, p. 174) - offered one of the reasons for writing the book ("Die sogenannte 'Anti-Pädagogik' war einer der Anlässe für dieses Buch" ibid.). Another crucial reason being the apparent "pathlessness" which is characteristic of 'our' condition. "What is remarkable and new is ... an educational aporia, a pathlessness intrinsic to upbringing - one that we can accept as our own" (Mollenhauer 2014, p. 5). Five years later, in the foreword of another yet untranslated book: Umwege. Über Bildung, Kunst und Interaktion (Mollenhauer 1986) (Detours. On Bildung, Art and Interaction), Mollenhauer repeats that thinking about "Bildung und Erziehung" has become difficult so that we might even say that the pedagogical era has come to a provisional end - "als wäre die pädagogische Konjunktur an ein vorläufiges Ende gekommen" (Mollenhauer, 1986, p. 7). In such a situation, we might need detours in order to think (about) education (i.e. that there is a necessity to take "cultural products' in the largest sense as starting point in order to broaden the issues that educationalists take into account in theory and practice (Ibid., p. 11)). But, let us stay with Mollenhauer's endeavor in Forgotten Connections.

As he writes himself, it is an attempt to recall "the old questions: to find out whether something along the lines of fundamental principles exist for modern educational practice" (Mollenhauer 2014, p. 6). In order to appreciate the contemporary relevance of this intellectual move, which responds to a particular context, it is important to try to clarify what is at stake. First of all, it is very striking and important that Mollenhauer, who was one of the main proponents of critical pedagogy and critical educational theory, now seems to question the reach of his own critical approach as one that has become totally counter-productive and is even threatening proper educational thought. One could say that he actually distances himself from a critical tradition of philosophy of education that judges theories and practices, and he now proposes to attempt a 'positive' articulation of educational theory. And it is clear that Mollenhauer, by recalling "the old questions", is establishing himself consciously a ('forgotten') connection to a tradition of educational thought that started with Schleiermacher (to whom Mollenhauer refers often throughout all of his work) and wanted to identify some basic and particular 'features', which would characterize the educational phenomenon and especially the pedagogical relationship. This should offer the starting point for the elaboration of a proper educational thought or general study (called "Allgemeine Pägogik" or simply "Pädagogik"). It is in line with this tradition that Johann Friedrich Herbart claimed and elaborated "einheimische Begriffe" ('internal concepts'), that Wilhelm Flitner suggested and requested a "pädagogischer Grundgedankengang" ('basic pedagogical thought'), and that Erich Weniger, Mollenhauers teacher and himself a student of Herman Nohl, reclaimed an unalterable principle that is inherent to the pedagogical attitude of the educator: to be interested in the personal formation of the educandus and, more generally, to take sides with the human being that has been entrusted to him or her ("eine Parteinahme des Erziehers für den ihm anvertrauten Menschen"). ${ }^{1}$

However, although Mollenhauer is clearly connecting to this tradition, claiming strongly the necessity of recalling the old questions, it is important to notice that he also slightly but decisively displaces them. This displacement threatens to be overlooked by the English translation. Indeed, in German, Mollenhauer is not recalling 'questions' but just 'the old question' ("die alte Frage"), but more importantly he is not using the word 'principles' but "Elementaria" (even between inverted commas in the original), and there is not only a reference to 'educational practice' but also to modern educational thought since the German "Pädagogik" is essentially also referring to 'theory': "In einer derartigen Situation ist es nützlich, an die alte Frage zu erinnern, ob es so etwas wie "Elementaria" neuzeitlicher Pädagogik gebe ..." (1983, p. 6). It is, in itself, certainly very defendable to translate 'elementaria' to 'principles' (and 
Mollenhauer is using the notion 'Prinzipien' earlier in the text). But this notion is often associated with rules, standards or guidelines (as Mollenhauer himself also indicates) whereas in this context Mollenhauer suggests precisely a far more problematizing endeavor, being aware very much of what he called the "pathlessness" or aporia of education. As he explains, in German, he is concerned about: "einen Minimalkanon von Problemstellungen ..., die heute niemand ignorieren sollte, der verantwortlich erziehen will, und zwar gleichviel, an welcher Stelle unseres Erziehungs- und Bildungssystems er tätig ist” (1983, p. 16). This is now adequately translated as: "a basic set of issues and questions that no one who wants to raise and educate children in a principled manner could ignore, regardless of their position in our systems of education" (Mollenhauer 2014, p. 6). In fact, the way Mollenhauer is recalling the "old question' testifies of his awareness that our condition has changed, and that the "Elementaria" that he is offering later on (Presentation, Representation, Bildsamkeit, Self-activity, Identity) are not to be seen as 'inherent concepts' but indeed as radically open, elementary "issues and questions". And, later, in "Umwege" (1986), he will question explicitly whether we could even formulate such "Elementaria" and if we should not limit ourselves to simply indicate that education is also a cultural phenomenon and that, thus, in order to 'think education' we can or even should include cultural artifacts.

Nevertheless, although admittedly speculated-upon to some extent, Mollenhauer never lost his attachment to the 'old question' and the concern for the proper place of educational thought. It was one of the reasons to be present at the aforementioned seminar in Hamburg in 1989. Reenacting Mollenhauer's intellectual endeavor to indicate a proper place for educational thought by trying to formulate some elementary issues and questions is crucially relevant today. Indeed, in a time where we are confronted not so much with a sociological or ideological colonization, but with the omnipresence of (bio-) psychological approaches (including the apparently unavoidable 'learning discourse') towards the educational field and, moreover, with an ever-pervasive emptying of traditional frames of meaning, the question of 'elementary issues' deserves to be taken up and emphasized once again. Besides the fact that we could and should reconsider all the issues and questions Mollenhauer is dealing with. And that his descriptions and analyses remain very worthwhile and relevant - they should be read, I believe, by any student of education. I think, however, that in an attempt at reenacting Mollenhauer's endeavor today, there is at least one elementary issue that also has to be rephrased or complemented.

In the second chapter of his book Mollenhauer is dealing with the issue of 'representation'. Since the $17^{\text {th }}$ century, he states, education has been conceived as the art of representation, related to justification and explanation. Indeed at least since Comenius published Orbis sensualium pictus (The World in Pictures) in 1658, education has been concerned with presenting the world 'once more' i.e. to re-present it in a 'critical' way. I feel that translating the original German "die Welt "noch einmal"” (1983, p. 53) in a more literal way as "the world 'once more', instead of "reproducing' the world" as it is actually translated (Mollenhauer 2014, p. 35), allows a more fortunate indication of a crucial educational issue, as I will clarify below. The whole of forms of life is so confusing that, according to Comenius, it must be presented to the child or the young 'in the right order'. Since then, according to Mollenhauer, the central questions of any education seems to be: What, in view of the enormous amount of subject matter, should be learned? And how can what is considered worthwhile be transmitted to the new generation?

One could state indeed that modern education is about the world 'once more'; the world explained and represented in a 'right order' in response to a reigning confusion. However, as Mollenhauer himself remarks, in the last century this idea of representing the right order has been strongly complicated by the increasing awareness of the implied problem: How is the representation related to what it represents? Mollenhauer refers to the Belgian painter René 
Magritte who offered maybe one of the strongest and most famous images of this problem. He made a painting of a pipe with the caption, 'Ceci n'est pas une pipe'. This is not a pipe, but a painted pipe and one cannot decide whether the painted pipe represents the 'real' pipe. This means that when we let children 'see the world', we don't show them the world, but what we see as the world, and what we consider to be important, valuable and useful about it. Therefore, educators do not only have to think about the 'right' representation but should be aware that they are not showing the world, but representing it: 'ceci n'est pas le monde'. And then the questions seem to appear again, and even more emphatic as with the seventeenth century thinker Comenius: What do we have to represent and how to represent it?

These questions, at least at first sight, still seem to be the ones we have to ask today, certainly in view of the tremendous expansion of what is available to be learned through the omnipresence of the Internet. However, it seems on second sight that the transformation of the educational field in a 'learning environment' implies also the transformation of these questions into questions regarding the empirical preferences and needs of (individual) learners so that it is as if it ceases to be an elementary educational issue that anyone in the educational field should consider. Moreover, my hypothesis is that the problem of education in our (post-modern) times is shifting, or there is at least an additional 'elementary issue'. Not only because we moved from education to learning and to 'learning to learn' as the main aim (thereby seemingly solving the problem of 'what to learn'), but also because our condition has become (and is increasingly becoming) a virtual and perspectival one. In contrast to the very common idea in educational theory and philosophy that one of our main endeavors in education should be to raise a critical awareness with students that every 'world' is but a view on the world - just one vision, one perspective, each and every person having her own perspective so that we have a plurality of perspectives and that everything is an interpretation - 'ceci n'est pas le monde', but a vision on the world, a 'window', 'a frame', I would maintain that today this awareness is very widely spread and indeed has become the basic stance. Moreover, I am inclined to agree with Gumbrecht that our contemporary everyday more

than ever before, $[\ldots]$ has turned into an everyday of only virtual realities, into an everyday where modern communication technologies have given us omnipresence and have thus eliminated space from our existence, into an everyday where the real presence of the world has shrunk into a presence on the screen. (Gumbrecht, 2014, p. 8)

And I would suggest that it confronts education with an issue that is, so to speak, opposite to the critical modern one. Not: How to represent the world and how to make students aware that this representation is not the 'real world'? This awareness is present enough. But, how to turn the world into something 'real', how to make the world 'present', to give again the real and discard the shields, screens and mirrors that seem to have locked us into self-reflections and interpretations, endless returns upon 'standpoints', 'perspectives' and 'opinions'. This problem, I think, is neither an epistemological one (about true representations) nor a normative one (regarding what to value, what to select), but is precisely about the (dis-)stance i.e. the way we relate to the world, it is about the right distance which opens up an existential space. It is not about the problematic of representation the way Mollenhauer suggested. Indeed this problematic has been debated in all (im)possible ways (its relation to the real and to illusion, its subjectivity or objectivity, its historical, social, cultural determinations, etc.). But, it is about a movement, not beyond what is visible, but towards its very work or power, not only to make the world known (in an ordered way), but to make it 'real' or 'present'.

Education, then, is still about giving the world 'once more' - not its right representation, but its 'presentation' in the literal sense: making it present (again). The given must 
be given again in order to become really given. To give again the given is to 'realize' it, to insist on its present and presence. This is not a mere matter of vision or of the symbolical representation of a cognitive or cultural content (or a story or a frame). The world 'once more' is not about a 'reliable reflection of reality' (Mollenhauer 2014, p. 46) or an 'original' reality behind (the vision, perspective) but about its evidence, the 'there-is' or 'being there'. If, as Gumbrecht states, "[i]t is safe to say that [today] all of us feel a special yearning for moments of presence in our broad present. [...] a will-to-presence" (Gumbrecht 2014, p. 79) then we are confronted not only with the issue of what to represent, but also with the question of how to make it present, how to ensure it becomes real, how to (re-)give it some authority (to make it speak to us in the strong sense). This is not a psychological issue of motivation, but an existential issue in relation to our world. It could be considered as the indication of an extreme radicalization of what Mollenhauer himself called the "lack of educational force" of our concrete forms of life $(2014$, p. 46) and therefore to be an elementary educational issue of our times.

\section{Endnotes}

i. In fact, even in his 'critical' book entitled Theorien zum Erziehungsprozess (1972) Mollenhauer tried to indicate some structural elements that characterized the educational field. It strengthens the impression that he always has been more close to this particular pedagogical tradition than to the tradition of Critical Theory.

\section{References}

Gumbrecht, H. U. (2014). Our broad present. Time and contemporary culture. New York: Columbia University Press.

Mollenhauer, K. (1983). Vergessene Zusammenhänge. Über Kultur und Erziehung. München: Juventa.

Mollenhauer, K. (1986). Umwege. Über Bildung, Kunst und Interaktion. München: Juventa.

Mollenhauer, K. (2014). Forgotten connections. On culture and upbringing. London: Routledge.

Peukert, H. (1992). Ortsbestimmung der Erziehungswissenschaft. Wilhelm Flitner und die Frage nach einer allgemeinen Erziehungswissenschaft im 20.Jahrhundert. Weinheim: Beltz. 